\title{
VIRTUÁLIS KIÁLLÍTÁS SZERVEZÉSE AZ INNOVÁCIÓS STÚDIUM (2020/2021) KERETÉBEN
}

\section{Szerzők:}

Mező Ferenc (PhD)

Eszterházy Károly Egyetem

Mező Kristóf Szíriusz

$\mathrm{K}+\mathrm{F}$ Stúdió Kft.

Első szerző e-mail címe:

ferenc.mezo1@gmail.com

\section{Lektorok:}

Pšenáková Ildikó (PhD)

Trnavská Univerzita v Trnave (Slovakia)

Borbélyné dr. Bacsó Viktória (PhD)

Medgyessy Ferenc Gimnázium,

Mûvészeti Szakgimnázium és Technikum

...és további két anonim lektor

\begin{abstract}
Absztrakt
Az „Innovációs Stúdió (2020/2021)” a K+F Stúdió Kft. egyik tehetséggondozó projektje, amelyet a Magyar Nemzeti Tehetség Program támogat. E program keretében virtuális kiállítás is készítül az „OxIPO” virtuális múzeum számára. Jelen tanulmány felvázolja a virtuális kiállítások szervezésének tartalmi, módszertani és szoftverfejlesztési szempontjait.
\end{abstract}

Kulcsszavak: virtuális, kiállítás. OxIPO

Tudományterület: interdisciplinary

\section{Abstract \\ ORGANIZING A VIRTUAL EXHIBITION \\ IN THE FRAMEWORK OF THE 'INNOV ATION STUDIO (2020/2021)'}

The 'Innovation Studio (2020/2021)' is one of the talent development projects of the K+F Stúdió Kft. (R\&D Studio Ltd.) that supported by Hungarian National Talent Program. In the frame of this program, a virtual exhibition will be also created for the 'OxIPO' Virtual Museum. The present study outlines the content, methodological and software development aspects of the organization of virtual exhibitions.

Keywords: virtual, exhibition, OxIPO

Disciplines: interdisciplinary

Mező Ferenc és Mező Kristóf Szíriusz (2021): Virtuális kiállítás szervezése az Innovációs Stúdium (2020/2021) keretében. Mesterséges intelligencia - interdiszciplináris folyóirat, II. évf. 2020/2. szám. 53-58. doi: 10.35406/MI.2020.2.53 
Többek között virtuális kiállítás megvalósítása is szerepel a $\mathrm{K}+\mathrm{F}$ Stúdió Kft. „Innovációs Stúdium 2020/2021” címmel megvalósuló tehetséggondozó programjában, amelyet a Nemzeti Tehetség Program támo-gat az NTP-PKTF-20-0009 azonosítószámú pályázat keretében (a program részleteivel kapcsolatban lásd: Mező és Mező, 2020).

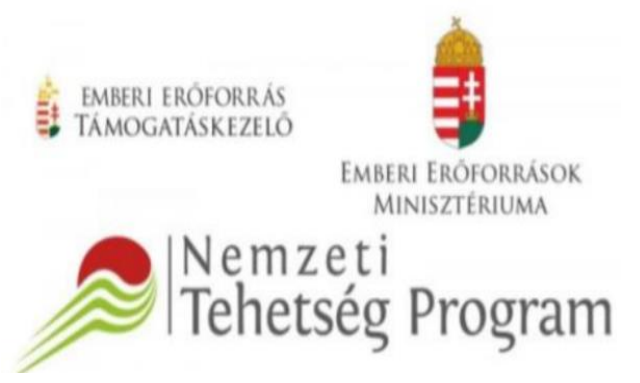

A virtuális kiállítás $2 \mathrm{D}$ vagy 3D látványt nyújtó, csak a számítógép képernyőjén (esetleg hangszóróján) keresztül megtapasztalható kiállítás. Sajátossága, hogy a Covid-19 vírusbetegség okozta világjárvány idején is alkalmas lehet a kultúraközvetítésre, hiszen akár saját otthonából tekintheti és ismerheti meg a kiállítás anyagát minden látogató. Ha-bár a virtuális élmény merőben más, mint a valódi térben megtörténő múzeumlátogatás (ami napjainkban még nem pótolható a virtuális megoldásokkal), mégis igen sok érv felhozható a virtuális kiállítások mellett is. De hangsúlyozzuk: nem a valódi térben megva- lósuló kiállítások ellen szólnak ezek az érvek, hanem a virtuális kiállítások mellett - v.ö.. 1. táblázatot a múzeum/virtuális múzeum összevetésről.

Egy virtuális kiállítás két főbb összetevőből áll. Az egyik a tartalmi összetevő, a másik a szoftver jellegű komponens, ami a tartalmi összetevőt közvetíti a felhasználó felé. Mindkettőre különös figyelmet kell fordítani, különösen, ha a kiállítást múzeumpedagógiai célokra (is) fel kívánjuk használni.

$\mathrm{Az}$ alábbiakban röviden vázoljuk e két komponens lényegesebb aspektusait, majd kitérünk a virtuális múzeumok pedagógiai szereplehetőségeire is.

\section{Virtuális kiállítások}

\section{tervezésének tartalmi szempontjai}

A virtuális kiállítás tartalma gyakorlatilag bármilyen téma lehet, amit képző-, zenemûvészeti vagy irodalmi, illetve ismeretterjesztő jelleggel digitális eszközök használatával közvetíteni lehet a közönség felé. Így arra is lehetőség van, hogy akár a ,mesterséges intelligenciával kapcsolatos innováció" témát körbejáró mûvészeti vagy ismeretterjesztő kiállítás valósulhasson meg (tekintve, hogy a mesterséges intelligencia és az innováció témák önmagukban is izgalmasak, de össze is függhetnek). Ha az adott témába vágó installációk alkotását a máskülönben viszonylag passzív „közönség” szerepét betöltő szeméylekre bízzuk, akkor részükről nagyobb bevonódást érhetünk el a téma, s általában a virtuális kultúraközvetítés terén. 
1. táblázat: a hagyományos és virtuális múzeumok összevetése (forrás: Mező K. és Mező F, 2020, 93. o.)

\begin{tabular}{|c|c|c|c|}
\hline \multicolumn{2}{|c|}{ Összehasonlítási szempont } & Múzeum & \multirow{2}{*}{$\begin{array}{l}\text { Virtuális } \\
\text { múzeum }\end{array}$} \\
\hline Fenntartási & Ingatlan: & • & \\
\hline szükséglet, & Gazdasági forrás: & $\bullet$ & $>$ \\
\hline \multirow[t]{2}{*}{ költségek } & Humán eröforrás: & $\bullet$ & $>$ \\
\hline & Informatikai: & - & $\bullet$ \\
\hline A látogatót érö & Láttányélmény: & $\checkmark$ & $\sqrt{2}$ \\
\hline lehetséges & Hangélmény: & $\checkmark$ & $\checkmark$ \\
\hline \multirow[t]{5}{*}{ élmények ${ }^{\mathrm{b}}$} & Tapintásélmény: & $\sqrt{b}$ & $x$ \\
\hline & Illatélmény: & $\sqrt{b}$ & $x$ \\
\hline & Izélmény: & $\sqrt{b}$ & $x$ \\
\hline & Mozgásélmény: & $\checkmark$ & $x=$ \\
\hline & Installációk:saját testméret arány élménர̧e: & $\checkmark$ & $x$ \\
\hline \multirow[t]{4}{*}{ Biztonság } & Látogatót/munkatársat érő baleset vagy fertổzés esélye: & $\bullet$ & $>$ \\
\hline & Installációkat éró sérülés esélye: & $\bullet$ & $>$ \\
\hline & Installációk eltulajdonításának esélye: & - & $\bullet$ \\
\hline & Adatlopás esélye: & - & $\bullet$ \\
\hline \multirow[t]{4}{*}{ Szolgáltatások } & Állandó kiállitások & $\checkmark$ & $\checkmark$ \\
\hline & Idōszaki kiállítások & $\checkmark$ & $\checkmark$ \\
\hline & Tárlatrezetések & $\checkmark$ & $\checkmark$ \\
\hline & Múzeumpedagógia: & $\checkmark$ & $\checkmark$ \\
\hline Kiegészítõ & 24 órás nyitra tartás: & $? d$ & $\checkmark$ \\
\hline szolgáltatások & Ajándékbolt: & $\checkmark$ & $\sqrt{ }=$ \\
\hline
\end{tabular}

23D installációk új nézőpontból (például felülnézetböl) történö megtekintése is lehetséges.

- Megjegyzendö, hogy a kiallitási tárgyak megérintése sok esetben tilos (ilyen esetekben a tapintással kapcsolatos élménỵeket a hagyományos múzeumban sem szerezhet a látogató), az üvegtárlókba zárt tárgyaknak nem érzödik az illata, a kiállítási tárgyak megkóstolása (ital- és ételkiállítások ritka kivételétöl eltekintve) nem jellemzö...

' Kinekt-szerü technológián alapuló virtuális múzeumban a mozgásélmény (például a kiállitáson történö séta élménye) is biztositható.

${ }^{d A} 24$ órás nyitva tartás elvileg lehetséges a hagyományos múzeumok esetében, de nem jellemzö.

'Virtuális múzeum esetében webáruház valósíthatja meg az ajándékbolt jellegũ szolgáltatást 
A kiállított/elhangzó kompozíciók lehetnek 2D grafikák, festmények, fényképek, audio-video bejátszások, vagy éppen 3D alkotások.

A kiállítások művészeti és/vagy tudományos-ismeretterjesztő jellege, illetve a kiállított installációk techinkai vonatkozásainak kombinációnak tervezését szemlélteti és segíti a 2. táblázat.

2. táblázat: virtuális kiállitások technikai és müvészetil tudományos-ismeretterjesztố jellege szerinti lehetséges kombinációk (forrás: a Szerzőo).

\begin{tabular}{|l|l|c|}
\hline \multirow{2}{*}{ Technika } & \multicolumn{2}{|c|}{ Jelleg } \\
\cline { 2 - 3 } & Múvészet & $\begin{array}{c}\text { Tudományos } \\
\text { ismeretterjesztő }\end{array}$ \\
\hline Grafika & & \\
\hline Festmény & & \\
\hline Fotó & & \\
\hline Audio/video & & \\
\hline 3D konsteláció & & \\
\hline
\end{tabular}

A virtuális kiállítások tartalmi tervezésekor figyelembe vehető főbb szempontok (nem feltétlenül fontossági sorrendben):

1. A kiállítás témája,

2. A kiállítás célja,

3. A kiállítás célközönsége (például életkor, előzetes tudás, a kiállítás nyelvének ismerete, stb. szempontjából),

4. A kiállítás szervezői köre (tartalmi tervezők, megvalósítók, programozók, a téma szaktanácsadói, producerek, PRmarketing stáb, stb.),
5. A kiállítási installációk alkotói köre (ha eltér a szervezői krörtől), s bevonásuk (felkérés, pályáztatás?),

6. A kiállítás szín- és formavilága (a virtuális tér színei, a kiállított installációk színei),

7. Az egyes installációk és az egész kiálítás kompozíciója,

8. Az installációk megtekintésének tervezett sorrendjét érintő virtuális tér megtervezése (a kiállítás bejárásának menete, tervezett időtartamok, a bejárást segítő tájékoztató táblák és útirányt mutató jelölések tervezése),

9. A kiállítás installációinak készítési technikája (grafika, festmény, fotó, stb.),

10. Az egyes installációkhoz tartozó szöveges információk (cím, forrás, leírás, esetleg feladat stb.) és előállításuk tervezése,

11. A kiállításhoz tartozó kiegészítők előállításának terve (promóciós dokumentumok, plakátok, közösségi médián keresztül közreadható emblémák és hirdetések, album, reklámfilm, ajándékés/vagy emléktárgyak, stb.),

12. A kiállításhoz kapcsolódó oktatási és /vagy múvészeti, egyéb kulturális tevékenységek, attrakciók, játékok terve.

13. A közönség megszólítása a virtuális kiállítás megtekintése érdekében.

14. A virtuális kiállítás megnyitása, annak módja, dátuma, időpontja, meghívottjai.

15. A virtuális kiállítás fenntartásának, továbbfejlesztésénk tartalmi aspektsai (péládul: lehetséges új altémák megjelölése). 
A fenti pontok alapján talán érzékelhető, hogy számos tartalmi pont egyeztetésére van szükség ahhoz, hogy a virtuális kiállítás eljusson a szoftverfejlesztési szakaszba. Létezik egy fordított hatás is: a szoftver fejlesztés aktuális lehetôségei meghatározhatják, hogy milyen tartalmi elemek kerülhetnek egy virtuális kiállításba.

\section{A virtuális kiállítások szoftverfejlesztési aspektusai}

A virtuális kiállítások létrehozása szoftverfejlesztési szempontból lényegében három főbb feladat megoldását jelentik. Az első, a műalkotások és/vagy tudományos-ismeretterjesztő alkotások digitalizálása (például grafikák szkennelése, helytörténeti szempontból lényeges műemlékjellegû épületek fotózása és/vagy 3D modellezése, stb. vegyük észre, hogy egy szkennelés és egy 3D modell elkészítése különböző idő-, energia-, szaktu-dásbeli befektetést igények!). E téren mérlegelni szükséges péládul:

1. A digitális alkotások létrehozásához rendelkezésre álló vagy elérhető hardverek, szoftverek körét, beszerzési lehetőségeit (ezzel együtt árát).

2. A digitális alkotások előállítóit. Ők lehetnek hagyományos módon (például: papír-ceruza felhasználásával...) vagy számítógépen alkotó mûvészek, infografikusok, tudományos-ismerettereteket terjesztő kutatók, pedagógusok, művelődési menedzserek egyéb szakemberek. Természetesen a humánerőforrással összefüggő gazdasági szempontokat is célszerű figyelembe venni (péládul: tisztelet-, jog-, egyéb munkadíjakat és ezek járulékait).

A szoftverfejlesztés másik feladata a digitalizált tartalmakat egy virtuális térben megjelenítő, a felhasználó számára a virtuális térben mozgási, esetleg további interaktivitási lehetőséget biztosító szoftver létrehozása. A tervezés itt ebben az esetben is egyrészt a megfelelő szoftver/hardver kiválasztására, másrészt a programozók személyéra, s mindezekkel kapcsolatos kiadásokra kell, hogy koncentráljon.

Végül, a kész szoftver offline vagy online formában történő közzétételét is meg kell valósítani. Ehhez adott esetben akár külön (al)domain regisztrációra és a kiválasztott tárhelyen elhelyezett weblap létrehozására is szükség lehet. Amihez még a késztermékkel kapcsolatos marketing is hozzávehető. Ennek következtében a tervezéskor át kell tekinteni a rendelkezésre álló vagy beszerzendő tárhelyek, domain-ek, webszerkesztő szoftverek és a mindezekkel kapcsolatos ügyintézés, webfejlesztés, marketing tevékenység biztosításának lehetőségeit és költségeit.

\section{Virtuális kiállítások múzeumpedagógiai aspektusai}

A múzeumi tanulásról, múzeumpedagógiai foglalkozásokról szóló szakirodalmak (például: Vásárhelyi és Kárpáti, 2011; Vágolva, 2013) megállapításai nagy vonalakban alkalmazhatók a virtuális kiállítások, múzeumok kontextusában is. A lényeg az, hogy egy-egy 
virtuális kiállitáson keresztül is tervezhetők és megvalósíthatók nevelési-oktatsi célok.

A virtuális kiállítások révén történő nevelésnek, oktatásnak van egy előnye a hagyományos, múzeumlátogatás keretében történő múzeumpedagógiai foglalkozásokkal szemben. Noha a gyermekek, tanulók mûveiből alkotott kiállításokat a hagyomános múzeumokban is megvalósíthatunk (gondoljuk például gyermekrajz kiállításokra), azok többnyire csak időszakos jelleggűek, míg egy virtuális kiállítás hosszabb időn át fennálló, állandó kiállítás is lehet.

Különösen hatékony lehet, ha a nevelni, oktatni szánt diákok nemcsak befogadói, látogatói, hanem alkotói is a kiállításoknak. Ennek oka: a) a kiállítások motiválhatják a tanulókat egy adott témával való foglalkozásra (anyaggyűjtésre, feldolgozásra, összefoglalására); b) a témába történő bevonódás koncentráltabb szellemi tevékenységet, gondolkodást, elmélyülést eredményezhet; c) egyfajta hősterápiaként szolgálhat akár a gyengébben teljesítő, esetleg a lemorzsolódás határán lévő tanulók számára is.

A virtuális kiállításhoz kapcsolódóan nemcsak tartalmában, hanem jellegében is változatos feladatok, feladatsorok állíthatók össze. Néhány példa a különböző feladattípusokra:

1. Zárvégű feladatok:

1.1. Igaz-hamis döntést igénylő feladatok (akár a virtuális térben történő mozgással, interakcióval is lehet válaszolni);

1.2. Feleletválasztós feladatok. 3-6 választási lehetőség közül történhet a felhasználó által megfelelőnek vélt válasz jelölése (akár virtuálsi térben történő mozgssal is).

1.3. Egyszavas vagy szám(sor)os kiegészítést igénylő feladatok. A megoldást egy szövegmezőbe írhatja a felhasználó, s a zárt választ azonnal értékelheti a szoftver, ami alapján visszajelzést adhat, illetve a válaszhoz alkalmazkodva adhatja a következő feladatot - lényegében programozott oktatást valósíthat meg.

1.4. Relációanalízis jellegű feladatok: két vagy több állítás igaz/hamis voltát és a köztük lévő kapcsolat relevanciáját kell a válaszadónak megítélnie.

2. Nyitott végű feladatok. Például többszavas kifejtést, komplex rajzolást stb. igénylő feladatok válaszainak beküldését vagy egy embernek vagy egy erre a célraa fejlesztett MI-nek kell értékelnie.

Érzékelhető, hogy miközben mind a zárt-, mind a nyitott végű feladatok kiadásában hasznos lehet a szoftveres megoldás, az mégis elsősorban a zártvégű feladatok értékelésében nyújthat segítséget.

\section{Összefoglalás}

A virtuális kiállítások a mesterséges intelligencia és az azzal kapcsolatos innováció témában is megvalósíthatók, akár szélesebb tömegek aktív, alkotó bevonásával is. 
Az OxIPO Virtuális Múzeumban 2021-ben megtekinthető innovációs kiállításokhoz partnereket (magánszemélyeket, intézményeket) keresünk - kapcsolat: info@,kpluszf.com

\section{Irodalom}

Mező K. és Mező F. (2020). A múzeumpedagógia és a tehetséggondozás lehetőségei egy virtuális múzeumban. Külön- leges Bánásmód, 6. (3). 89-99. DOI 10.18458/KB.2020.3.89

Mező F. és Mező P. D. (2020): Innovációs Stúdium (2020/2021). OxIPO - interdiszciplináris tudományos folyóirat, 2020/4, 91-92.

Vágolva É. (2013). A tanórán kívüli oktatás és az élménypedagógia pszichológiai, pedagógiai szempontjai és előnyei. Levéltári Szemle, 63, 4, 61-71.

Vásárhelyi T. és Kárpáti A. (2011). Múzeumi tanulás. MTM-Typotex, Budapest. 